\title{
Improving lecturers' evaluation score by using analytic hierarchy process (AHP): a case at Universiti Kuala Lumpur
}

\author{
Nurashikin Saaludin ${ }^{1}$, Mohd Hafizul Ismail ${ }^{2}$, Basyirah Che Mat ${ }^{3}$, Suriyati Harun ${ }^{4}$ \\ ${ }_{1,2,3}$ Malaysian Institute of Information Technology (MIIT), Universiti Kuala Lumpur, Malaysia \\ ${ }^{4}$ British Malaysian Institute (BMI), Universiti Kuala Lumpur, Malaysia
}

\begin{tabular}{l} 
Article Info \\
\hline Article history: \\
Received Dec 10, 2018 \\
Revised Feb 12, 2019 \\
Accepted Feb 24, 2019 \\
\hline
\end{tabular}

Keywords:

Analytic hierarchy process Criteria

Lectures' evaluation

Pair wise comparison

\begin{abstract}
The quality of education is primarily determined by the academician expertise, skills, abilities and competencies. Poor quality of education will give bad impact to the institution. It is very important to enhance the quality of service to ensure the education system in Malaysia higher education is at par as international education standard. To achieve the international standard, the teaching quality of lecturers must be seriously taken into consideration. An appropriate method of lecturers' evaluation should be used to measure lecturers' performance and credibility. The purpose of this study is to improve the lecturers' evaluation score by using Analytic Hierarchy Process (AHP). AHP is used to obtain the weightage of each criterion in lecturers' evaluation. The results show that teaching delivery carries the highest weightage, followed by assessment, course content and course material, lecturer's interaction and lecturer's commitment criteria. By implementing a new method of calculation, the overall score will be more accurate in describing the overall lecturer's performance from students' point of view.
\end{abstract}

Copyright $@ 2019$ Institute of Advanced Engineering and Science. All rights reserved.

\section{Corresponding Author:}

Nurashikin Saaludin,

Malaysian Institute of Information Technology (MIIT),

Universiti Kuala Lumpur (UniKL), Malaysia,

1016, Jalan Sultan Ismail, 50250, Kuala Lumpur, Malaysia.

Email: nurashikin@unikl.edu.my

\section{INTRODUCTION}

Almost all education institutions in Malaysia use lecturers' evaluation to review and rate lecturers' teaching performance and effectiveness in the classroom. The findings from these evaluations are used to provide feedback to lecturers and guide their professional development. It cannot be denied that lecturers or academicians are the backbones of education institution, whose, their service will determine the institution success and reputation. Dorasamy and Balkaran [1] said that the evaluation not only to rate the teaching quality of the lecturers but also important in accessing the programme effectiveness. Yeoh et. al [2] who had done a research at private university confirmed that lecturer qualities are the most important indicator in determining lecturer performance which can improve students' satisfaction and the related university image. According to Seldin, Miller, and Seldin [3], students are considered as important stakeholders of the higher education institution system because they directly involved with the process of receiving knowledge and observing the way of their lecturers teaching in the classroom. Sok-Foon et. al. [4] in their study said that the lecturers' evaluation is a good indicator to be used in enhancing lecturers' development and students learning performance. Even though Machingambi and Wadesango [5] recommended that lecturers' evaluation of teaching should be made mandatory, they also stressed that it must be integrated with other multidimensional evaluation methods so that the validity and reliability of the evaluation of teaching effectiveness can be improved. This point of view is also agreed by Iyamu and Aduwa-Oglebaen [6], Archibong and Nja [7] and they thought that it was improper to use the lecturers' evaluation for promotion or salary increment purposes. 
Universiti Kuala Lumpur, as a technical university, with a tagline of 'Where Knowledge is Applied', has also adopted this good practice. Lecturers' evaluation has become one of the main criteria that is looked at for the annual key performance index (KPI) and promotion appraisal. As of now, UniKL has been using the relevant elements in assessing evaluation of lecturers' teaching performance from the students' perspective. The five main elements are lecturer's commitment, teaching delivery, lecturer's interaction, assessment and course content and material. Several other supporting points that are also being evaluated are punctuality, lecturers' knowledge and teaching approach. All the criteria used in lecturers' evaluation have the same weightage. Therefore, students' feedback might not fully reflect the actual teaching efficiency of the lecturers. An upward reweighting of the feedback scores of each criterion in lecturers' evaluation to ensure more parity in the teacher evaluation process should be proposed, so that the most important element will be given the highest weightage and so on.

AHP is proposed to be used as a tool to improve lecturers' score calculation by determining the new weightage for each criterion in lecturers' evaluation. The ambiguity of concepts that are associated with human being's judgments will be used to prioritize the criteria [8]. AHP is very flexible and is broadly employed in various fields to optimise distribution network, technology transfer, integrated manufacturing and performance appraisal $[9,10,11]$.

\section{LITERATURE REVIEW}

Teaching is, forever will be, one of the major duty of all universities. Thus, the quality of teaching should always be one of the fundamental objectives for the universities. Therefore, there is a need to assess teaching performance. The purposes of evaluating teaching performance are to build up lecturers' professionalisme, to support self-improvement and to look at suitable continuous quality improvement [9]. Assessing teaching performance is not a simple task, as it engage with human decision-making, which is loose, dubious and very subjective. Thus, using the scientific method to assess teaching performance exhaustively and adequately plays a vital role in deciding the quality of teaching performance.

Eduardo and Bruno [13] agreed to the idea that students' evaluation is used by some institutions as part of instruments for an academician to be promoted but they believed the questions or items asked in the evaluation form could be distorted in some undesirable ways especially by the variables that are beyond the lecturer's control. That is why, there is a need to look into and modify the items in students' evaluation form to avoid an academician being promoted or not, unfairly.

The adequacy of the evaluation process depends mostly on the proper design and assessment of the evaluation. Successful evaluation mechanism demands consideration in recognizing competencies of lecturers as well as establishing evaluation criteria specific to a different element of skills [14]. Lecturers' evaluation is very important for lecturers to internalize the students' feedback and make appropriate changes to their teaching styles and it is also important in strengthening the management of the university. The university can only give outstanding service to the community if it focuses on continuous quality improvement [12].

Besides teaching, lecturers are also obligated to meet students' expectation, maintain or improve the ratings of the university and to ensure that the graduates are well received in the job market [15]. Yin, Wang, and Han [16] investigation on the Chinese universities students assess on their lecturers' teaching revealed that favourite lecturers were described as knowledgeable about the educational curriculum, engage with the students, teaching beyond textbooks and examinations and adopting more students-centred teaching approaches.

Many studies have been done by researchers to identify the most suitable and appropriate elements to be included in lecturers' evaluation for the purpose of determining the lecturers' teaching competencies and professionalism. It can be a crucial reference to enhance the teaching quality offered. According to Vevere and Kozlinskis [17], the four key factors that are needed in lecturers' evaluation are knowledge transfer, knowledge evaluation, lecturers' personal traits as well as lecturers' accessibility. They also stressed that the relationship between lecturers and students is the most important item in analysing the lecturers' performance because the attitude of lecturers has a high impact towards the students' ability in their learning process.

In 2015, a study which was done by Phillips, Balan and Manko [18], suggested that there were five crucial components in measuring the teaching performance. The components are classified as lecturers' planning and preparation, an environment of the study place, instructional delivery, professionalism and collaboration and partnership. However, only the first four components were meant to be rated by students as the last component has no relation with teaching and learning.

In Malaysia, other higher institutional educations also opted to execute the teaching evaluation aside from Universiti Kuala Lumpur. Universiti Teknologi Malaysia for example, has implemented Lecturer 
Performance Assessment (ePPP) which look into four main parts; i) Planning and Preparation ii) Delivery Methods iii) Assessment and iv) Students-Lecturers Relation. The ePPP also allowed the respondents to give a view in the comment section for detailed elaborations [19]. In the same research paper, Samian and Noor also emphasized that the students' achievements had a high positive correlation with two criteria that are the delivery skills and the relation of lecturers and students. They, at once, disagreed with the claim that the lecturers' evaluations are invalid when it comes to be a benchmarking of teaching effectiveness, as stated in some studies. The traditional method of teaching is still powerful and crucial in getting beneficial information on lecturers' teaching performance.

As the lecturers' evaluation is worldwide used and accepted, a few researchers have concentrated on assessing teaching performance in universities and several methods have been used in enhancing the details in lecturers' evaluation as well as the calculation of the data obtained. Previous studies mainly focused on the details of students' evaluation with minority examined the quantitative method on getting the information based on the students' evaluation [20]. Since the students' evaluation consist of many different criteria, the suitable method of accessing the correct information from data obtained is crucial.

AHP, a well-known tool in aiding in decision-making process when dealing with multiple criteria. This method is considered as a good method that can solve complicated decision matters with easily accessible input data [21]. Recently, Yousif and Shaout [22] combined AHP and TOPSIS method to evaluate teaching quality. TOPSIS was introduced to overcome the pairwise comparison in AHP due to uncertainty in the decision maker's judgement. The combined method has been a good application of AHP theory in evaluating teaching performance. Chen, Hsieh and Do [12] also proposed an approach of teaching performance evaluation with fuzzy AHP. This study focuses on improving lecturers' evaluation criteria or items, applicable in Universiti Kuala Lumpur by using the AHP.

\section{RESEARCH METHOD}

\subsection{Research Design}

Data was collected by distributing a questionnaire to a few decision makers who are responsible in designing and implementation of this evaluation. Among the respondents are Deputy Director, Senior Manager and Coordinator of UniKL Centre of Instructional Technology and Curriculum (CITC). The input from Deputy Dean Academic and Technology and Heads of Section of UniKL Malaysian Institute of Information Technology (UniKL MIIT) also have been considered to streghthen the outcome of study.

\subsection{Criteria for Lecturers' Evaluation}

The lecturers' evaluation is carried out once in every semester by all institutes of UniKL through the online system. Five criteria are used as a domain of evaluation and is illustrated in Figure 1. Further explanation about the criteria used in lecturers' evaluation are shown in Table 1.

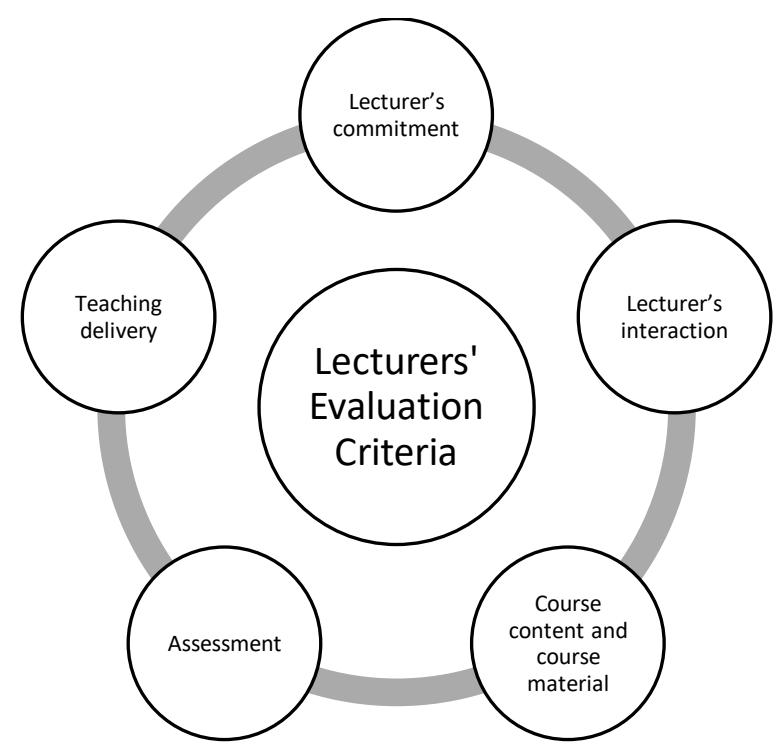

Figure 1. Lecturers' Evaluation Criteria 
Table 1. Explanation about Lecturers' Evaluation Criteria

\begin{tabular}{ll}
\hline \multicolumn{1}{c}{ Criteria } & \multicolumn{1}{c}{ Explanation } \\
\hline $\begin{array}{l}\text { Lecturer's } \\
\text { commitment }\end{array}$ & $\begin{array}{l}\text { Lecturer has good time management, always on time in each task given, very concern about } \\
\text { students' academic achievement, arranges immediately class replacement and provide constructive } \\
\text { feedback to students on each assessment. } \\
\text { Lecturer uses English as a medium of interaction while teaching, well-prepared, knowledgeable, } \\
\text { enthusiastic, explains well the subject matters through real life situations and uses variety of } \\
\text { teaching methods in conducting lecture. }\end{array}$ \\
Lecturer's interaction & $\begin{array}{l}\text { Lecturer constantly encourages students' participation in class, provide sufficient time for } \\
\text { consultation, approachable and ready to entertain students' questions regarding to subject taught. } \\
\text { Lecturer assesses students' cognitive and soft skill based on the learning outcomes of the course. }\end{array}$ \\
Assessment & $\begin{array}{l}\text { Lecturer also always firm and fair in evaluating students' assessments. } \\
\text { Content and teaching materials delivered by lecturer are neatly prepared and easily understood and } \\
\text { course material. }\end{array}$ \\
\hline
\end{tabular}

\subsection{Analysis Method}

AHP method by Saaty [8] has been used in this study to determine the priorities of importance (weights) to the main criteria of the lecturers' evaluation. This method is an effective approach in decision making for selecting the best alternative to identify the overall score of lecturers' evaluation.

AHP provides a structured framework for setting priorities by using pairwise comparisons. Comparing the process of criteria for their relative importance is necessary to be been done as shown in Figure 2. The relative importance using 1 to 9 scale of criteria for every paired criteria is illustrated in Table 2.

Table 2. Saaty's Scale of Relative Importance

\begin{tabular}{cl}
\hline Importance Intensity & \multicolumn{1}{c}{ Definition } \\
\hline 1 & Equal importance \\
3 & Moderate importance of one ever another \\
7 & Strong importance of one over another \\
9 & Very strong importance of one ever another \\
$2,4,6,8$ & Extreme importance of one over another \\
\hline
\end{tabular}

$$
\text { Criteria } C=\left[\begin{array}{lllll}
c_{11} & c_{12} & c_{13} & c_{14} & c_{15} \\
c_{21} & c_{22} & c_{23} & c_{24} & c_{25} \\
c_{31} & c_{32} & c_{33} & c_{34} & c_{35} \\
c_{41} & c_{42} & c_{43} & c_{44} & c_{45} \\
c_{51} & c_{52} & c_{53} & c_{54} & c_{55}
\end{array}\right]=\left[\begin{array}{ccccc}
1 & c_{12} & c_{13} & c_{14} & c_{15} \\
\frac{1}{c_{12}} & 1 & c_{23} & c_{24} & c_{25} \\
\frac{1}{c_{13}} & \frac{1}{c_{23}} & 1 & c_{34} & c_{35} \\
\frac{1}{c_{14}} & \frac{1}{c_{24}} & \frac{1}{c_{34}} & 1 & c_{45} \\
\frac{1}{c_{15}} & \frac{1}{c_{25}} & \frac{1}{c_{35}} & \frac{1}{c_{45}} & 1
\end{array}\right]
$$

Figure 2. Pair wise Comparison Matrix

The implementation of AHP continued by the normalization of pair wise comparison. The normalisation of comparison matrix was computed by dividing each entry of the column with the summision of entries for every column of comparison matrix as shown in Figure 3 and Figure 4. In the following process, the mean value of the numbers on each row of the normalized comparisons matrix is computed. The calculated mean values represent the relative weight of decision elements with matrix rows as shown in Figure 5. Multiplication Matrix C and Weight as shown in Figure 6. 


$$
\left[\begin{array}{ccccc}
c_{11} & c_{12} & c_{13} & c_{14} & c_{15} \\
c_{21} & c_{22} & c_{23} & c_{24} & c_{25} \\
c_{31} & c_{32} & c_{33} & c_{34} & c_{35} \\
c_{41} & c_{42} & c_{33} & c_{44} & c_{45} \\
c_{51} & c_{52} & c_{53} & c_{54} & c_{55} \\
\sum_{i=1}^{5} c_{i 1} & \sum_{i=1}^{5} c_{i 2} & \sum_{i=1}^{5} c_{i 3} & \sum_{i=1}^{5} c_{i 4} & \sum_{i=1}^{5} c_{i 5}
\end{array}\right](2)
$$

Figure 3. Sum of Entries for Every Column

$$
\bar{W}=\left[\begin{array}{c}
w_{1} \\
w_{2} \\
\vdots \\
w_{5}
\end{array}\right]=\left[\begin{array}{c}
\frac{w_{11}+w_{11}+\ldots+w_{15}}{5} \\
\frac{w_{21}+w_{22}+\ldots+w_{25}}{5} \\
\frac{w_{51}+w_{52}+\ldots+w_{55}}{5}
\end{array}\right]
$$

Figure 5. Relative Weight

$$
N=\left[\begin{array}{lllll}
w_{11} & w_{12} & w_{13} & w_{14} & w_{15} \\
w_{21} & w_{22} & w_{23} & w_{24} & w_{25} \\
w_{31} & w_{32} & w_{33} & w_{34} & w_{35} \\
w_{41} & w_{42} & w_{43} & w_{44} & w_{45} \\
w_{51} & w_{52} & w_{53} & w_{54} & w_{55}
\end{array}\right]
$$

Figure 4. Normalized Comparisons Matrix

$$
C \bar{W}=\left[\begin{array}{lllll}
c_{11} & c_{12} & c_{13} & c_{14} & c_{15} \\
c_{21} & c_{22} & c_{23} & c_{24} & c_{25} \\
c_{31} & c_{32} & c_{33} & c_{34} & c_{35} \\
c_{41} & c_{42} & c_{43} & c_{44} & c_{45} \\
c_{51} & c_{52} & c_{53} & c_{54} & c_{55}
\end{array}\right]\left[\begin{array}{l}
w_{1} \\
w_{2} \\
w_{3} \\
w_{4} \\
w_{5}
\end{array}\right]
$$

Figure 6. Multiplication Matrix C and Weight

Consistency Ratio (CR) will be used to determine the consistency and reliability level of the result. Pairwise comparison may look simple, but when the number of comparisons arises, the level of confidence on the consistency of comparison is not simply accepted and it requires the CR. According to Dyer and Forman [23], if the reading of CR is less than 0.1, the consistency of comparisons will be acceptable and it can be concluded that all the judgements are consistent and valid, otherwise the criteria comparisons should be reconsidered. The following steps are needed to calculate the value of CR:

i) Multiply matrix $\mathrm{C}$ with weight, $\bar{W}$ as shown in Figure 6.

$$
C \bar{W}=\left[\begin{array}{lllll}
c_{11} & c_{12} & c_{13} & c_{14} & c_{15} \\
c_{21} & c_{22} & c_{23} & c_{24} & c_{25} \\
c_{31} & c_{32} & c_{33} & c_{34} & c_{35} \\
c_{41} & c_{42} & c_{43} & c_{44} & c_{45} \\
c_{51} & c_{52} & c_{53} & c_{54} & c_{55}
\end{array}\right]\left[\begin{array}{l}
w_{1} \\
w_{2} \\
w_{3} \\
w_{4} \\
w_{5}
\end{array}\right]
$$

ii) Compute $\lambda_{\max }=\frac{1}{5} \sum_{i=1}^{n} \frac{\text { entry- } i \text { in } C w}{\text { entry- } i \text { in } w}$

iii) Compute the consistency index, $C I=\frac{\lambda_{\max }-5}{4}$

iv) The appropiate random index value is taken from Saaty's CR random number (RI) index as shown in Table 3.

Table 3. Saaty's CR Random Number Index

\begin{tabular}{cccccccccc}
\hline Size of Matrix & 2 & 3 & 4 & 5 & 6 & 7 & 8 & 9 & 10 \\
\hline RI & 0 & 0.52 & 0.89 & 1.12 & 1.26 & 1.36 & 1.41 & 1.46 & 1.49 \\
\hline \multicolumn{1}{c}{$C R=\frac{C I}{R I}$} \\
the consistency ratio, CR by comparing the CI with RI,
\end{tabular}




\section{RESULT AND DISCUSSION}

UniKL students are required to complete and submit the lecturers' evaluation form, for every lecturer who is teaching them for that particular semester. One of the reasons for implementing the evaluation is to measure the teaching quality among UniKL lecturers. In measuring the lecturers' teaching quality, AHP method was used to determine the weightage of each criterion in lecturers' evaluation based on priority. Table 4 below shows the result of analysis.

Table 4. Comparison Matrices and Weightage for Each of Lecturers' Evaluation Criteria

\begin{tabular}{|c|c|c|c|c|c|c|}
\hline \multicolumn{7}{|c|}{ Consistency Ratio $=0.0906$} \\
\hline Criteria & $\mathrm{A}$ & $\mathrm{B}$ & $\mathrm{C}$ & $\mathrm{D}$ & $\mathrm{E}$ & Weightage \\
\hline A & 1 & 0.11111 & 0.25 & 0.14286 & 0.125 & $\begin{array}{c}0.03075 \\
(3.075 \%)\end{array}$ \\
\hline B & 9 & 1 & 9 & 3 & 3 & $\begin{array}{c}0.46471 \\
(46.471 \%)\end{array}$ \\
\hline $\mathrm{C}$ & 4 & 0.11111 & 1 & 0.125 & 0.125 & $\begin{array}{c}0.05648 \\
(5.648 \%)\end{array}$ \\
\hline $\mathrm{D}$ & 7 & 0.33333 & 8 & 1 & 1 & $\begin{array}{c}0.22058 \\
(22.058 \%)\end{array}$ \\
\hline $\mathrm{E}$ & 8 & 0.33333 & 8 & 1 & 1 & $\begin{array}{c}0.22748 \\
(22.748 \%)\end{array}$ \\
\hline
\end{tabular}

Indicator:

A - Lecturer's commitment

B - Teaching delivery

C - Lecturer's interaction

D - Assessment

E - Course content and course material.

The finding shows that teaching delivery carries the highest weightage if compared to other criteria. To produce quality teaching, a lecturer needs to be knowledgable, enthusiastic and creative in various teaching methods. The above criteria formed the largest weightage which is $46 \%$ of overall lecturers' evaluation. Meanwhile, assessment and course content and course material criteria is the second and third largest criteria with $22.7 \%$ \& $22.05 \%$ weightage respectively. The ranking of these three criteria is agreed by Hubackova [24], Chen, Hsieh and Do [12]. According to Hubackova, students rank teacher's professional knowledge in the first place, the contents of material learnt, second and teacher's pedagogical abilities, third. Whereas, Chen, Hsieh and Do opined that well prepared and using a variety of approaches in teaching delivery are the most important criteria in lecturers' performance. The remaining criteria namely lecturer's interaction and lecturer's commitment formed the balance of $8.7 \%$ weightage in lecturer evaluation.

The overall score for the lecturer is derived by multiplying the weightage of respective criteria and the rating given by students to lecturers. The example of the calculation is shown in Table 5. The overall score from Table 5 reflects the teaching efficiency of the lecturer since the weightage of criteria is considered in calculation as compared to the current method that only use student rating average as an overall score as shown in Table 6.

Table 5. Overall Score Calculation using Weightage from AHP

\begin{tabular}{lcccc}
\hline Criteria & Student's rating & Weightage & Score & Overall Score \\
\hline Lecturer's commitment & 4.60 & 0.03075 & 0.14145 & 4.093 \\
Teaching delivery & 3.55 & 0.46471 & 1.649721 & \\
Lecturer's interaction & 4.54 & 0.05648 & 0.256419 & \\
Assessment & 4.56 & 0.22058 & 1.005845 & \\
Course content and & 4.57 & 0.22748 & 1.039584 & \\
course material. & & & & \\
\hline
\end{tabular}

Table 6. Overall Score Calculation using Average Student's Rating Average

\begin{tabular}{lcc}
\hline Criteria & Student's rating & Overall score \\
\hline Lecturer's commitment & 4.60 & 4.364 \\
Teaching delivery & 3.55 & \\
Lecturer's interaction & 4.54 & \\
Assessment & 4.56 & \\
Course content and & 4.57 & \\
course material & & \\
\hline
\end{tabular}

Indonesian J Elec Eng \& Comp Sci, Vol. 15, No. 1, July 2019 : 391 - 398 
The overall score from Table 5 reflects the teaching efficiency of the lecturer since the weightage of criteria is considered in the calculation as compared to the current method that only use student rating average as an overall score as shown in Table 6. The proposed method can be used as an indicator of the top management to evaluate lecturers from the perspective of students' point of view.

The CR is 0.0906 . The ratio is less than 0.1 as fixed by Saaty [8]. Hence, the judgment given by respondents were considered as consistent, the weightages produced are valid and aligned with other several studies Salgado et al. [25, 26].

\section{CONCLUSION}

AHP has been proven and accepted as an effective and efficient method in decision making worldwide. This method incorporates qualitative and quantitative factors that can be used as a tool in determining the weightage of criteria for lecturers' evaluation. The correct weightage for each criterion is very important because it will reflect the ranking or priority of the elements being used in measuring the teaching efficiency of the lecturers. From the score, lecturers will know the criteria that they should focus more and thus, improve accordingly. It will also enable them to disseminate knowledge and skills for the students' benefits. The calculation of inconsistency ratio is a very important feature to ensure the decision made cannot be disputed in the outcome. In order for UniKL to drive towards education revolution 4.0, lecturers are the backbone who should start the transformation in educating and preparing students for selflearning skills, able to think critically, creative and innovative especially to prepare them for the future workforce.

\section{ACKNOWLEDGEMENTS} (str17088)

This paper has been supported by Universiti Kuala Lumpur (UniKL) through STRG Grant

\section{REFERENCES}

[1] Dorasamy, N., \& Balkaran, R. (2013). "Role of Student Ratings of Lecturers in Enhancing Teaching at Higher Education Institutions: A Case Study of The Durban University of Technology".

[2] Yeoh, S.F., Ho, S. Y. \& Chan, Y. F. "Student Evaluation of Lecturer Performance Among Private University Tudents, Canadian Social Science Vol. 8, No. 4, pp. 238-243, 2012.

[3] Seldin, P., Miller, J. E., \& Seldin, C. A. "The Teaching Portfolio: A Practical Guide to Improved Performance and Promotion/Tenure Decisions". John Wiley \& Sons, 2010.

[4] Sok-Foon, Y., Sze-Yin, J. H., \& Yin-Fah, B. C. (2012). "Student Evaluation of Lecturer Performance Among Private University Students", Canadian Social Science, 8(4), 238-243. [5].

[5] Machingambi, S., \& Wadesango, N. "University Lecturers' Perceptions of Students' Evaluation of Their Instructional Practices. The Anthropologist", 13(3), 167-174, 2011.

[6] E. O. S. Iyamu and S. E. Aduwa-Oglebaen, "Lecturers' Perception of Student Evaluation in Nigerian Universities," Int. Educ. J., vol. 6, no. 5, pp. 619-625, 2005.

[7] Archibong, I. A., \& Nja, M. E. "Towards Improved Teaching Effectiveness in Nigerian Public Universities: Instrument Design and Validation". Higher Education Studies, 1(2), 2011, 78-91.

[8] T. L. Saaty. "Decision Making with the Analytic Hierarchy Process". International journal of services sciences, 1(1), 2008, 83-98.

[9] S. Kumar, S. Luthra \& A. Haleem. "Benchmarking Supply Chains by Analysing Technology Transfer Critical Barriers using AHP Approach”. Benchmarking: An International Journal, 22(4), 2015, 538-558.

[10] T. Rochmat, "The Decision Support System Design of Employee Performance Appraisal using Analytical Hierarchi Process (AHP) Method," Proc. Intl Conf Inf. Syst. Bus. ..., pp. 283-288, 2012.

[11] M. J. Sharma, I. Moon, and H. Bae, "Analytic Hierarchy Process to Assess and Optimize Distribution Network," Appl. Math. Comput., vol. 202, no. 1, pp. 256-265, 2008.

[12] J. F. Chen, H. N. Hsieh, and Q. H. Do, "Evaluating Teaching Performance Based on Fuzzy AHP and Comprehensive Evaluation Approach,” Appl. Soft Comput. J., vol. 28, pp. 100-108, 2015.

[13] Eduardo C. A. and Bruno P. R. "Factors Affecting the Student Evaluation of Teaching Scores: Evidence from Panel Data Estimation". Estud. Econ. Vol. 42, no. 1, 2012.

[14] Sing O. Yu, "Reassessing the Teaching Evaluation Process: Case Study of a Malaysia Private University," Int. J. Recent Sci. Res., vol. 7, no. 4, pp. 10436-10440, 2016.

[15] Hall, C., Swart, W. and Duncan, S., "Balancing Customer Needs and Standards in Higher Education," Quality Approaches in Higher Education, Vol. 3, No. 1, 2013.

[16] H. Yin, W. Wang, and J. Han, "Chinese Undergraduates' Perceptions of Teaching Quality and The Effects on Approaches to Study and Course Satisfaction," High. Educ., vol. 71, no. 1, pp. 39-57, 2016.

[17] Vevere, N. \& V. Kozlinskis. "Students' Evaluation of Teaching Quality". US-China Education Review B 5: 702-708, 2011.

Improving lecturers' evaluation score by using analytic hierarchy process (AHP)... (Nurashikin Saaludin) 
[18] Phillips, K.F., Balan, R.M., \& Manko, T.P. “Teacher Evaluation. Improving the Process". Teaching and Learning Journal, 7, 2014.

[19] Samian, Y., \& Noor, N. M. "Students' Perception on Good Lecturer Based on Lecturer Performance Assesment". Procedia-Social and Behavioral Science, 2012, 56.

[20] Thanassoulis, E., Dey, P.K., Petridis, K., Goniadis, I. \& Georgiou, A.C. "Evaluating Higher Education Teaching Performance Using Combined Analytic Hierarchy Process and Data Envelopment Analysis”, J. Oper. Res. Soc. 68, 431-445, 2017.

[21] Triantaphyllou, E. and Mann S. H. "Using the Analytic Hierarchy Process for Decision Making in Engineering Applications: Some Challenges". International Journal of Industrial Engineering: Applications and Practice. Vol. 2, No. 1, pp. 35-44, 1995.

[22] M. K. Yousif and A. Shaout, "Fuzzy Logic Computational Model for Performance Evaluation of Sudanese Universities and Academic Staff," J. King Saud Univ. - Comput. Inf. Sci., vol. 30, no. 1, pp. 80-119, 2018.

[23] R. F. Dyer and E. H. Forman, "Group decision support with the Analytic Hierarchy Process," J. Advert. Res., vol. 8, pp. 99-124, 1992.

[24] Hubackova, S. "Factors Influencing the Quality of Teaching and the Foreign Language Knowledge". ProcediaSocial and Behavioural Sciences, 197, 1952-1956, 2015.

[25] E. G. Salgado, E. R. S. da Silva, C. E. S. da Silva and C. H. Pereira Mello. "An Analytic Hierarchy Process Analysis for Small and Medium Sized Enterprises: Prioritizing The Practices of Total Quality Management in Bazil". International Journal for Quality Research, 9(2) 2015.

[26] E. G. Salgado, E. R. S. da Silva, C. E. S. da Silva and C. H. Pereira Mello. "Prioritising the Practices of Total Quality Management: An Analytic Hierarchy Process Analysis for the Service Industries", Total Quality Management \& Business Excellence, 22(12), 1331-1351, 2011.

\section{BIOGRAPHIES OF AUTHORS}

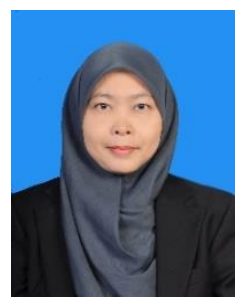

Nurashikin Saaludin is currently a Senior Lecturer at Universiti Kuala Lumpur, Malaysian Institute of Information Technology, Malaysia. Her research interest is in the Statistics and Social Sciences areas.

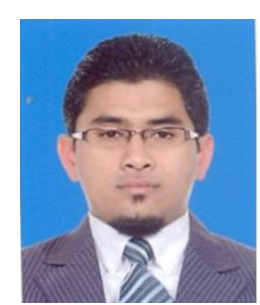

Mohd Hafizul Ismail is currently a Lecturer at Universiti Kuala Lumpur, Malaysian Institute of Information Technology, Malaysia. His research interest is in engineering management, IT management and Korean Language

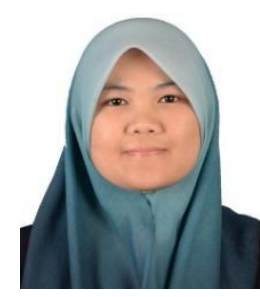

Basyirah Che Mat is currently a Lecturer at Universiti Kuala Lumpur, Malaysian Institute of Information Technology, Malaysia. She has interest in doing research and publish a research paper in Mathematical and Statistical fields especially in forecasting and simulation.

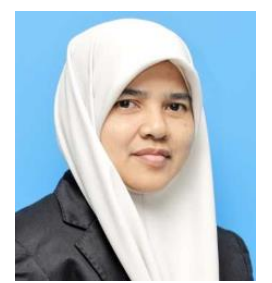

Suriyati Harun is currently a Senior Lecturer at Universiti Kuala Lumpur, British Malaysian Institute, Malaysia. She has keen interest in doing research in the area of Mathematics, social science and also in teaching and learning. 